\title{
Preventive Diplomacy Efforts in Iraq between the Power and Morals Standards
}

\author{
Inass Abdulsada Ali and Hussein Mezher Khalaf \\ Assistant Professor of International Studies, University of Baghdad/College of Political Science, Iraq
}

\begin{abstract}
With the end of the Cold War era, it was expected that both interstate and intrastate conflicts would decline. The end of the Cold War reduced the East-West ideological competition that often instigated both intrastate and interstate disputes. Ironically, these crises and conflicts did not disappear as much as multiplied and evolved in different forms, especially intrastate. This situation has called international society to urge diplomatic efforts for solving or, at least, settle these crises and conflicts. The 1990s decade has witnessed an upsurge of international society involvements in peacekeeping, peacebuilding, peacemaking, and even reconstruction of war-torn states.

The application of conflict resolution around the world, especially concerning incidents of large-scale armed conflict and wars, is largely dominated by duplicity in dealing due to the conflicting interests of the various international powers that influencing the resolutions. This raises several questions regarding the interventions that come under the name of preventive diplomacy. Wherefore, we are trying in this article to clarify this dilemma "the inconsistency", and searching for a suitable mechanism to resolve it, and spotlight on Iraq as a case study.

The study of preventive diplomacy and the contradiction between its means that including the use of power, and what are the moral restrictions imposed on it, consider the most important topic that sparked debates among specialists.

The goal of preventive diplomacy is to prevent the potential conflicts from happening, at the same time, preventive diplomacy resorted to the use of hard means, such as hard power, to achieve its goals, and that it may not be acceptable by the conflict parties, and this led to the finding a gap between the means of application of preventive diplomacy on one hand and the acceptability of these means by the disputing parties on the other hand.

This paper has used a descriptive approach for analyzing data, and reliance on the analysis of information contained in the references which used in the research.
\end{abstract}

\section{Practical Suggestions:}

To create a successful and effective preventive diplomacy, we suggest the following:

The Department of Peacekeeping Operations (DPKO) need to think innovatively about the current disproportionate emphasis on elections as the natural conclusion to a peace process, and about more inclusive and sustainable ways to nurture democratic governance, such as with enhanced support through checks and balances, a free press, and strong judiciaries. Attention to the role of political opposition parties to counter the winner-takes-all mentality is also important.

International powers must refrain from direct interference in the internal affairs of states 
under the pretext of implementing preventive diplomacy.

Paying attention to the process of framing the concept of preventive diplomacy and the mechanisms to implement it without being employed by international powers to serve their interests.

Ensure sufficient and flexible financing for preventive action.

Study the micro-determinants of success in preventive action.

Keywords; Iraq; PD; Power; Moral Standards. 